\title{
Sciendo
}

\section{ASEM's First Two Decades: A Role Discovered}

\author{
Mathew Doidge \\ National Centre for Research on Europe, \\ University of Canterbury \\ Logie, Level 4, \\ Christchurch 8140, New Zealand \\ E-mail: mathew.doidge@canterbury.ac.nz
}

Abstract: This article examines the first two decades of the transregional AsiaEurope Meeting (ASEM) from its inception with the Bangkok Summit of 1996. Examining instances of region building and the socialisation of states, it identifies the gradual emergence of a role for the forum, one that stands in some contrast to initial participant expectations. In this respect, rather than a structure for delivering substantive negotiated outcomes around issues such as trade liberalisation, the value of ASEM across its first 20 years came increasingly to be seen in its ideational aspects: identity building, norm diffusion, and dialogue without preconceptions.

Keywords: Asia-Europe Meeting, the European Union, interregionalism, transregionalism, the Asia-Pacific region

\section{Introduction}

The Asia-Europe Meeting (ASEM) is an iteration of the broader phenomenon of interregionalism that has gained greater currency in international relations over the last five decades, given additional impetus in the post-bipolar period by the emergence of new regionalisms and their prioritisation of engagement with counterpart groupings. Traceable to the first Yaoundé Convention, concluded between the European Union (EU) and the Associated African States and Madagascar in 1963, group-to-group interregional structures were at the outset an innovation of EU external relations, which have, in succeeding years, gained broader recognition as a mechanism of engagement, and have consequently 
become a seemingly indelible feature of the international system. That the place of such structures in international relations and global governance has been firmly established is evident in their recognition by, among others, the WTO Secretariat (Crawford \& Fiorentino, 2005) and the World Bank (2005).

Simply stated, interregionalism constitutes formalised engagement between groupings of states from different regions, each coordinating to a greater or lesser degree (Hänggi, 2006, pp. 39-40). This group-to-group organising principle is central to the definition of interregionalism which is, therefore, in essence a binary structure, even if at times only notionally (Doidge, 2011, pp. 2-3). ${ }^{1}$ Under this umbrella, two forms are identifiable. The first- bilateral interregionalism (Rüland, 1999, pp. 2-3) - constitutes relations between regional organisations (e.g., EU-MERCOSUR, ASEAN-Andean Community). The second - transregionalism - involves dialogues in which at least one of the partner groupings is not a regional integration arrangement, but rather a more-orless coordinated grouping of states (e.g., EU-LAC, FEALAC). ASEM falls into this latter grouping. Importantly, transregionalism is a more recent phenomenon than bilateral interregionalism, and indeed the first iteration of this variant was the Asia-Europe Meeting itself. As a consequence, ASEM became both the template according to which other similar structures were modelled, as was most notably the case with the Forum for East Asia-Latin America Cooperation (FEALAC) (Doidge, 2011, pp. 164-165), while also being forced to break new ground in terms of establishing a role for itself. It is in this context that this article will consider the Asia-Europe Meeting, examining early expectations as to its role and its consequent evolution over the two decades from its inception in 1996. In so doing it will highlight the way in which certain expectations concerning the forum have transitioned from an emphasis on ASEM as an instrument of substantive Asia-Europe cooperation, to one in which community-building and engagement have come to the fore.

APEC thus does not constitute an interregional forum. While it engages states from multiple regions, it lacks the regional mechanisms of coordination to be expected of interregionalism. As Hänggi (2006, p. 40) notes, APEC was conceived as a regional endeavour, and as a consequence is best characterised as a form of 'megaregionalism'. 


\section{ASEM: origins and expectations}

ASEM's origins are to be found in a series of meetings convened in the Singaporean Ministry of Foreign Affairs and the Prime Minister's Office during August 1994 to explore mechanisms for improving the Asia-Europe relationship (Pou Serradell, 1996, p. 186). These discussions are generally held to have been the product of Prime Minister Goh Chok Tong reading too much into the Commission's 1994 New Asia Strategy (Forster, 1999, p. 752): while the document highlighted a need to push for increased European economic presence in Asia, and to deepen the relationship as a means to extend its role as a global actor (Communication from the Commission, $\operatorname{COM}(1994) 314$ final), the reality was that these elements constituted something of a rhetorical flourish rather than the clear, focused statement of intent that Goh perceived. Nevertheless, despite initial European reticence or, in the case of German Chancellor Helmut Kohl, open hostility (Camroux \& Lechervy, 1996, p. 443) toward the concept, the Singaporean proposal was eventually accepted by the Council of Ministers meeting under the French Presidency in 1995. Reservations on a new AsiaEurope forum were not solely the domain of the Europeans, however, with ASEAN being forced to exercise considerable diplomacy in recruiting the Northeast Asian states to the cause: Japan in particular was concerned that the new structure would negatively impact its close relationship with the United States, while China feared that it would serve simply as a means to single it out for criticism (Camroux \& Lechervy, 1996, pp. 443-444). In spite of this initial scepticism, however, ASEM was quickly added to the roster of international fora, being launched in March 1996 with the convening of the first Summit in Bangkok.

As the first forum of its type, there was no clear model on which to base the functioning of ASEM cooperation. In the absence of prior experience from which to draw, two elements in particular served to structure expectations: (i) the influence of the forum for Asia-Pacific Economic Cooperation (APEC); and (ii) the core economic concerns evident among the founding members. APEC influence derived from the context in which ASEM emerged, with the new forum conceived as filling a "missing link" in interregional relations. This view stemmed from the apparent triadisation of the global economy in which economic de-territorialisation and integration within and between the regions of Europe, North America and Asia were deepening at a pace greater than the broader global trend (Ruigrok \& van Tulder, 1995, p. 151). Such economic processes had been accompanied by the building of corresponding interregional dialogue structures between these three core regions in the form of trans-Atlantic 
relations and the APEC framework, with the notable exception of a formal tie between Europe and Asia. Goh Chok Tong's proposal was designed to plug this gap, with the call for "Pacific-style" ties between the two positing the new forum as something of a mirror to APEC. With this link drawn, the Asia-Pacific forum inevitably served to structure certain expectations as to the role and functioning of the new Asia-Europe dialogue. While APEC had been operative since 1989, it convened its first Summit in 1993, at which time agreement around a set of reciprocal trade concessions was reached. When this was followed in 1994 by the tabling of plans for a Pacific Free Trade Area, the forum was seen as having taken a significant step forward, leaving behind its reputation as a talking shop in favour of the pursuit of substantive results. Conceived in this context, it was expected that ASEM would move rapidly towards the achievement of concrete outcomes, particularly in the area of trade liberalisation.

Alongside the influence of APEC, expectations for ASEM were also structured around the economic concerns of the founding members, most notably fears of marginalisation. In the early 1990s, the EU had undertaken a reappraisal of its ties with Asia, motivated largely by concern that its competitors - the US and Japan - were stealing a march in the region, and the need to gain a share of the high rates of growth occurring in the Asian economies. The resulting New Asia Strategy (Communication from the Commission COM(1994)314 final) made it clear that the primary factor underpinning the EU interest in an expansion of ties was unashamedly economic, with a focus on establishing mechanisms to mitigate potential economic marginalisation. Similar concerns were evident among the Asian states, and particularly the members of ASEAN, with perennial fears over the establishment of a "fortress Europe" enhanced as the common market neared completion (Yeung et al., 1999, p. 99). Such concerns were supplemented in the bipolar period by worries over potential trade diversion as a consequence of Europe's turn towards its eastern neighbourhood: EU exports to the Central and Eastern European countries had increased by 135\% between 1990 and 1995, and imports from the region by $93 \%$ (EUROSTAT, 2001). A link with Europe mirroring the economic and commercially focused tie with the United States embodied in APEC was therefore seen as essential (Pou Serradell, 1996, pp. 186-188).

Expectations of the Asia-Europe Meeting as an arena for high-end cooperation were, then, elevated from the outset, a situation made clear through the European Council's assertion that the new forum must pursue "concrete and substantial results" (European Council, 1995, p. 43). Notwithstanding the political element to the process, these substantive outcomes were conceived primarily in terms of trade and financial matters, and indeed it was around such issues that the early years of ASEM engagement were structured. Thus, following the first ASEM, 
separate sub-Summit fora were established for Economic and Finance Ministers, Senior Officials on Trade and Investment, and Customs Directors-General and Commissioners, alongside which was the creation of an Asia-Europe Business Forum. Further, the first steps were taken towards implementation of a Trade Facilitation Action Plan and an Investment Promotion Action Plan, raising the prospect that institutionalised rules and procedures would emerge to guide the facilitation and liberalisation of Asia-Europe trade and investment relations (Yeo, 2003, p. 155).

Despite the proliferation of such structures, however, the anticipated outcomes in terms of economic cooperation and trade liberalisation failed to eventuate, notwithstanding ongoing rhetorical commitment to these goals. Indeed, institutional proliferation in the absence of substantive engagement quickly became a characteristic of Asia-Europe cooperation, reflecting a form of "cooperation malaise" (Doidge, 2013, p. 151). The result was an increase in the breadth of the process, while depth of engagement remained notably limited: a case in many ways of much "sound and fury, signifying nothing". This failure is largely the product of two factors. First was an evident capabilityexpectations gap, with anticipated outcomes requiring a level of cooperation between the partner regions that proved difficult to achieve (Doidge, 2011, pp. 172-174). Second, exacerbating this, was the informal nature of the ASEM framework itself, influencing its ability to pursue concrete goals. The lack of an administrative secretariat, for example, meant that sub-Summit fora were often possessed of a certain amnesia regarding prior meetings, and as a consequence routinely ploughed the same ground with an attendant impact on the pace of cooperation (Commission official, cited in Doidge, 2011, p. 119). Similarly, the preference for soft law instruments and the non-binding and consensual nature of decision-taking limited cooperation, meaning that agreements may be taken only as indicative rather than substantive.

\section{A reconsideration of ASEM: role found?}

While calls for substantive engagement within ASEM continue, in practice it is broadly recognised that this goal is, at least currently, beyond the capacity of the forum to achieve. Instead, what became increasingly evident over the forum's first two decades was a reframing of its value in the eyes of participants as a political space, an ideational and discursive process, acting as a framework for dialogue and an arena for socialisation and norm diffusion, and consequently 
functioning both as a filter for global fora and as a mechanism for securitisation (Doidge, 2011, pp. 142-143). Intrinsic to this assignation of value has been the gradual accretion of experience in engagement, and the progressive layering of norms and practices of interaction, contributing to the establishment of shared identities and interests, the creation of a "we" feeling that underpins international relations and security. In this respect, ASEM may be seen in constructivist terms as a process of embedding "shared understandings, expectations, and social knowledge" (Wendt, 1994, p. 389), replacing threat perceptions with an element of mutual trust, and establishing a firmer foundation for Asia-Europe relations and thereby contributing to political and economic stability. In part, this altered view of ASEM has been premised upon a recognition of areas of apparent success, with two particular examples foremost among them: (i) the fostering of regional cooperation in Asia; and (ii) the process of socialisation of participant states into the international system.

\section{ASEM and Asian region-building}

In terms of fostering regional cooperation, ASEM has played a successful role in drawing together the member states of ASEAN with their Northeast Asian counterparts - China, Japan and South Korea. Where earlier visions of pan-Asian cooperation had been unsuccessful - including most notably the 1990 proposal from Malaysian Prime Minister Mahathir Mohamad for the establishment of an East Asia Economic Caucus (EAEC), a concept that proved unable to overcome opposition from the US and Japan who were concerned, among other things, with the potential consequences for APEC (Terada, 2003, p. 258) - the AsiaEurope Meeting is seen to have been instrumental in progressing intra-Asian cooperation. Much of this is attributable to the binary structure of ASEM which explicitly posits an Asian group alongside a European counterpart and reinforces this through the establishment of mechanisms of intraregional cooperation. At a very basic level, the first ASEM Summit in 1996 saw a relatively loose Asiacomprising the then seven ASEAN members and three Northeast Asian statesconfronted by a much more tightly coordinated "other" in the form of the European Union. ${ }^{2}$ This underlying asymmetry necessitated closer cooperation and coordination from the Asian states in order to be effective in the various ASEM fora, providing the motive force for subsequent efforts in this direction.

2 Characterised in terms of economic dialogue by the extent of its supranational actorness, and in political dialogue by the explicit attempt to coordinate to a higher level in ASEM than was usually the case (Doidge, 2011, p. 129). 
In practice, intra-Asian coordination preceded the first Summit in Bangkok, a response to the need to establish positions on a number of sometimes contentious issues, including the structure and agenda of the meeting. Given its position as convenor of ASEM 1, Thailand acted in the role of coordinator, facilitating a level of consensus which resulted in a joint Asian discussion paper on the future of the new forum. With the increasing demands for cooperative engagement resulting from the proliferation of structures in the wake of the inaugural Summit, this initial experience was seen as having been sufficiently positive to cement in place the coordinating role. In order to foster both intraregional cooperation and to provide guidance to the interregional process, a system of Joint Coordinators was therefore established, with the EU represented by the Presidency and the Commission, while the Asian states drew one Coordinator each from the ASEAN and Northeast Asian membership on a rotating basis.

The system of Coordinators and the ongoing need for engagement in preparation for meetings of the various ASEM fora subsequently provided a foundation for greater intra-Asian cooperation. With the US resiling from its earlier negative view of the EAEC concept, ${ }^{3}$ and the 1997 Asian financial crisis highlighting a need for East Asian solutions to regional problems in the face of a perceived lack of commitment by Western powers, the tentative process that had begun with ASEM was given something of a boost. As a result, December 1997 saw the convening of the first ASEAN+3 meeting in the margins of an informal ASEAN Summit, with agreement reached for a semi-formalisation of the grouping through the preparation of indicative agendas and the tasking of senior officials to explore follow-up activities and review the implementation of agreed initiatives. Subsequently, an East Asia Vision Group was established to plot a future path for ASEAN+3 cooperation, and an East Asia Study Group to review its recommendations including towards the establishment of an East Asia Summit (launched in 2005) and an East Asia Free Trade Area. In 2005, the forum was formalised with the signing of the Kuala Lumpur Declaration, which established joint goals and charted the future aim of establishing an East Asian Community. As it now stands, ASEAN +3 is an institutionalised and expansive process, comprising around 60 fora spanning a range of sectoral issues and involving engagement from the technical through to the Summit level. As such, it is seen as a significant outcome of the ASEM process (Hänggi, 2003).

3 Secretary of State for Business and Agricultural Affairs Joan E. Spero made clear at the 29th ASEAN Post-Ministerial Conference in Jakarta in 1996 that the US would no longer oppose the establishment of an EAEC-like structure, so long as this did not split the Pacific Rim (Stubbs, 2002, pp. 442-443). 


\section{ASEM and the socialisation of states}

In a related vein, the Asia-Europe Meeting is seen to have played a key role in the broader institutionalisation of international relations, most notably through facilitating socialisation into, and adherence to, the web of rules, norms and values that underpin global relations. Indeed, such has been defined as the greatest success of the forum (Commission official, cited in Doidge, 2011, p. 135). In the immediate post-bipolar period, there was some concern about instability in the international system: the lack of an overarching security concern drawing states together, combined with the new pre-eminence of economics in international relations, raised fears as to the inevitabilitly of a trade war among the core economic powers (Hänggi, 1999, pp. 58-59). As a consequence, systemic stability became something of a central concern, with a perceived need to further institutionalise international relations and to ensure that all states played by the same rules. ASEM constituted just such an institution, concerned with the implementation of global norms and standards (Forster, 1999, p. 744) or, less positively in the view of Cammack (1999, p. 14), with "imposing-developing and reinforcing - the hegemony capital". The Asia-Europe Meeting may therefore be seen as a mechanism for embedding both (neo)liberal economic rules and norms of political cooperation and engagement at the global level through the socialisation of its participant states. In this respect, the role of the forum in relation to China, and to a lesser extent Vietnam, is often highlighted (though it is with the former that the following discussion will be concerned).

China's rise as an economic, political and military power from the 1990s raised certain questions as to its external policies, generating considerable uncertainty around its political and military intentions in its immediate neighbourhood, as well as to whether it would be "an integrated member of the global economic community, or a pariah, an outsider, potentially a rogue" (CAEC, 1997, p. 61). A China not effectively integrated into the global system was seen as having the potential to become progressively more difficult to engage with (Maitland \& $\mathrm{Hu}, 1998$, p. 20). This need had been recognised by the European Union prior to the advent of ASEM, with an expressed intent to "integrate into the open, market-based world trading system those Asian countries such as China, India or Vietnam which are moving from state controls to market-oriented economies" (Communication from the Commission, $\operatorname{COM}(1994) 314$ final, p. 13). Indeed, it was with issues of non-compliance with multilateral trade rules that the majority of the EU's trade disputes with China were concerned (Dent, 1999, p. 144). As such, the integration of China into the WTO-led trade regime was identified as a priority. 
China was a member of the Asia-Europe Meeting from the outset, but until 2001 it was not a member of the WTO, despite having applied to join the multilateral trading structure as early as $1986 .{ }^{4}$ This lacuna between accession to ASEM and to the WTO therefore saw the former play an important part in drawing China further into the multilateral system. Multilateral norms underpinned the ASEM structure from the outset, with the first Summit formally adopting a "common commitment to market economy, open multilateral trading system, non-discriminatory liberalisation and open regionalism" (ASEM, 1996, §10) and to "complement and reinforce efforts to strengthen the $[\ldots]$ trading system embodied in the WTO" (ASEM, 1996, §11). Subsequently, as the ASEM process developed, a view that it was nested within the broader multilateral framework became firmly entrenched, reinforced for example through efforts to ensure that cooperation remained both WTO and UN consistent. This process was strengthened at the second Summit in 1998 which followed the onset of the Asian financial crisis. The product was a Statement on the Financial and Economic Situation in Asia (ASEM, 1998) which addressed the roles of the WTO, IMF and the World Bank in dealing with the crisis, and recognised the rules, norms and values of these institutions as underpinning the fabric of the global economy. The premising of ASEM cooperation on these multilateral rules helped to cement participants into the architecture of global governance, drawing in states such as China which had not previously been a part of that system, and providing an important training ground for engagement in multilateral diplomacy (Commission official, cited in Doidge, 2011, p. 140). In this respect, ASEM served both as a means for familiarising China with the expectations associated with involvement in WTO-led economic multilateralism, while at the same time effectively testing the resolve of Chinese leaders to participate. Indeed, so central to the economic pillar of ASEM was this socialisation function and drive to achieve Chinese (and Vietnamese) membership in the World Trade Organization that in the aftermath of their WTO accession this pillar of the dialogue was seen to have somewhat lost its way (Commission official, cited in Doidge, 2011, p. 140).

4 The Chinese application in 1986 was classed in terms of a "resumption of place". The Republic of China had been a founding member of the GATT (General Agreement on Trade and Tariffs) in 1948 but had withdrawn two years later as the Republic of China (Taiwan). The People's Republic of China therefore made the claim that the ROC's withdrawal was not legitimate as it had not been an expression of the will of the majority of Chinese. 


\section{ASEM re-evaluated}

These two examples of success share the underlying fact of dialogue and engagement. They are essentially discursive processes directed towards the building of identities and reaching common understanding, and the acceptance of core norms and practices, rather than toward the achievement of substantive outcomes. As noted previously, it is in these elements that the value of ASEM over its first two decades came increasingly to be seen to reside. As an informal process, ASEM is identified as an important arena for conducting dialogue on a range of issues without preconceptions and without any expectation that partners will be bound by discussions, thus increasing the willingness of those involved to address potentially contentious issues in an open fashion. In this respect, it serves as a useful mechanism for generating an understanding of positions and perspectives among a diverse array of states on issues of consequence, facilitating problem-solving and contributing to efforts at the global level. As such, the forum has proved beneficial in addressing issues, sometimes of a sensitive nature, which are not considered elsewhere-the Myanmar issue, for example. Further, given the breadth of ASEM's sub-Summit engagement, particular value has been found in the facility to organise specific meetings and working groups under the ASEM umbrella which may involve small or large sections of the broader membership and incorporate non-governmental and civil society actors, occur in single or multiple iterations, and involve simple information sharing or be seen as the foundation for greater cooperation on issues of specific sectoral interest, be this on sanitary and phytosanitary standards, customs and border control, quality assurance in higher education, child welfare or whatever the case may be. Finally, the density of ongoing interaction at all levels means that ASEM provides a context in which to establish direct personal contacts with a variety of partners, contributing to the building of trust and mutual understanding, the forging of shared identities, and, as a consequence, strengthening the foundations of regional stability and security.

This change in the way in which ASEM is conceived and valued has become widespread and can be seen in the forum's continuing expansion. From an initial membership of 26 ( 25 states plus the European Commission) to the current 53 (51 states plus the European Commission and the ASEAN Secretariat), this enlargement has continued despite the lack of concrete outcomes. Indeed, these newer member states, acceding in the period since the establishment of the Asia-Europe Meeting, were arguably possessed of a clearer understanding as to what the forum involves and can deliver than were its founders. That such states have entered with eyes wide open may be seen in the example of New Zealand. 
While initially New Zealand's interest in ASEM centred on the anticipation of substantive outcomes around trade liberalisation, by the time of its entry in 2010 this had been replaced by a view of the utility of the process in other areas. For New Zealand, ASEM serves two core functions: (i) as an arena for dialogue and access; and (ii) as a tool for reinforcing presence and identity. ASEM's role in facilitating dialogue and generating understanding is emphasised within the New Zealand Ministry of Foreign Affairs and Trade (MFAT), with awareness building around issues of regional significance seen as potentially the raison d'être of the forum (senior MFAT official, cited in Doidge, 2013, p. 155). Of particular significance has been the role of the Asia-Europe Foundation, the Governors' Meetings of which have generated dialogue on a range of topics in a manner not replicated elsewhere. Beyond this general process, however, the Asia-Europe Meeting is seen to offer specific benefit in facilitating access to Asian and European leaders and officials, with the opportunity to engage in bilateral or mini-lateral dialogue in the margins of the various ASEM fora. While this most obviously involves accessing larger powers, it also means engaging with smaller and more peripheral states (insofar as New Zealand is concerned) with which, due to limited foreign policy resources, relations may be only intermittent at best. In this is to be found, from the MFAT perspective, potentially the single greatest benefit of ASEM involvement (senior MFAT official, cited in Doidge, 2013, pp. 155-156).

Beyond such opportunities for dialogue and access, ASEM is also seen as a mechanism for reinforcing New Zealand's presence in the Asian region, a central goal of its foreign policy. Alongside participation in the EAS, APEC and the various ASEAN fora, the Asia-Europe Meeting is seen to provide an additional means for demonstrating New Zealand's Asian credentials, and to cement it more firmly into the Asian regional architecture (senior MFAT official, in Doidge, 2013, p. 156). In other words, the progressive layering of fora (including ASEM) within which New Zealand participates is part of a process of identity building, involving the assertion of a place as part of the Asian caucus, even if it is not necessarily an Asian state.

\section{Conclusion}

What seems clear then, is that, over the two decades since its inception at the Bangkok Summit in 1996, the role of the Asia-Europe Meeting-including, importantly, participant expectations around the forum-has evolved 
considerably. At the most basic level, this transition is a product of the place of ASEM as the first iteration of transregionalism, and therefore the lack of a pre-existing model on which to base initial expectations. The accrual of experience over the succeeding two decades therefore played an important part in defining the role and functioning of such structures. While anticipated substantive outcomes-particularly around trade liberalisation-have so far failed to eventuate, and indeed seem beyond the capacity of the forum to achieve, participants have increasingly come to recognise what the forum does do well. In this respect, ideational aspects such as identity building and norm diffusion, and the value of dialogue without preconceptions, have come to the fore, a product of the breadth and informal nature of engagement. What seems to be the case is that after twenty years of interaction the Asia-Europe Meeting has come somewhat into its own, carving out a role for itself in the increasingly densely institutionalised architecture of global governance. What remains to be seen is whether this vision of ASEM is unique to the Asia-Europe structure, or one that will come to characterise transregionalism more generally. In 1999, for example, the Forum for East Asia-Latin America Cooperation was launched. FEALAC was explicitly modelled on ASEM, both in its three-pillared institutional structure and in its modalities of cooperation, and showed a certain synergy of expectations around engagement, though interaction has been more limited and at a slower pace. Whether it undergoes a parallel transformation to its Asia-Europe counterpart, recognising similar value in the ideational and discursive components of interaction will provide a significant indicator as to the future of transregionalism.

Dr. Mathew Doidge is a senior research fellow at the University of Canterbury-based National Centre for Research of Europe, New Zealand. His research interests include the external relations of the EU, with a particular focus on EU development policy and on EU-Asia relations, the international political economy of development, and the Sustainable Development Goals. Currently, Dr. Doidge is involved in research projects on the EU and the SDGs, and on the Bologna process and the internationalisation of higher education in New Zealand. Dr. Doidge is the author of two books: The European Union and Interregionalism: Patterns of Engagement (Ashgate, 2011); and (with Martin Holland) Development Policy of the European Union (Palgrave, 2012). 


\section{References}

ASEM (1996), Chairman's Statement of the First Asia-Europe Meeting, Bangkok, 1-2 March. Retrieved from http://www.aseminfoboard.org/sites/default/files/ documents/1996\%20-\%20ASEM1\%20-\%20Chair\%20Statement.pdf [accessed 8 Jun 2015]

ASEM (1998), Chairman's Statement of the Second Asia-Europe Meeting, London, 3-4 April. Retrieved from http://www.aseminfoboard.org/sites/default/files/ documents/1998\%20-\%20ASEM2\%20-\%20Chair\%20Statement.pdf [accessed 8 Jun 2015]

CAEC (1997), The Rationale and Common Agenda for Asia-Europe Cooperation, CAEC Task Force Reports, London: Council for Asia-Europe Cooperation.

Cammack, P. (1999), 'Interpreting ASEM: Interregionalism and new materialism,' Journal of the Asia Pacific Economy, vol. 4, no. 1, pp. 13-32. https://doi.org/10.1080/13547869908724668

Camroux, D. \& Lechervy, C. (1996), “Close Encounter of a Third Kind?' The Inaugural Asia-Europe meeting of March 1996,' The Pacific Review, vol. 9, no. 3, pp. 442-453. https://doi.org/10.1080/09512749608719196

Communication from the Commission (COM (1994) 314 final) to the Council Towards a New Asia Strategy, Brussels, 13.07.1994. Retrieved from http://aei.pitt. edu/2949/1/2949.pdf [accessed 8 Jun 2015]

Crawford, J. A. \& Fiorentino, R. V. (2005), The Changing Landscape of Regional Trade Agreements, Discussion Paper, no. 8, Geneva: WTO Secretariat.

Dent, C. M. (1999), 'The EU-East Asia economic relationship: the persisting weak triadic link?' European Foreign Affairs Review, vol. 4, no. 3, pp. 371-394.

Doidge, M. (2011), The European Union and Interregionalism: Patterns of Engagement, Farnham: Ashgate.

Doidge, M. (2013), 'New Zealand and the Asia-Europe Meeting,' Asia Europe Journal, vol. 11, no. 2, pp. 147-162. https://doi.org/10.1007/s10308-013-0347-5

European Council (1995), 'Madrid European Council: Conclusions of the Presidency,' Bulletin of the European Union, no. 12, pp. 9-51.

EUROSTAT (2001), 'Intra-EU investment increased by 50\% in 2000,' News Release, no. 74/2001, 6 July.

Forster, A. (1999), 'The European Union in South-East Asia: continuity and change in turbulent times,' International Affairs, vol. 75, no. 4, pp. 743-758. https://doi. org/10.1111/1468-2346.00106

Hänggi, H.(1999), 'ASEM and the construction of the new triad,' Journal of the Asia Pacific Economy, vol. 4, no. 1, pp. 56-80. https://doi.org/10.1080/13547869908724670 
Hänggi, H. (2003), 'Regionalism through interregionalism: East Asia and ASEM,' in L. Fu-Kuo \& P. Régnier (eds.) Regionalism in East Asia: Paradigm Shifting? London: Routledge, pp. 197-219.

Hänggi, H. (2006), 'Interregionalism as a multifaceted phenomenon: in search of a typology,' in H. Hänggi, R. Roloff \& J. Rüland (eds.) Interregionalism and International Relations, Abingdon: Routledge, pp. 31-62.

Maitland, D. \& Hu, Y. S. (1998), Europe and Emerging Asia, London: Federal Trust.

Pou Serradell, V. (1996), 'The Asia-Europe Meeting (ASEM): a historical turning point in relations between the two regions,' European Foreign Affairs Review, vol. 1, no. 2 , pp. 185-210.

Ruigrok, W. \& van Tulder, R. (1995), The Logic of International Restructuring, London: Routledge.

Rüland, J. (1999), Transregional Relations: The Asia-Europe Meeting (ASEM) A Functional Analysis, Paper presented to the International Conference on Asia and Europe on the Eve of the 21st Century, Chulalongkorn University, Bangkok, 19-20 August.

Stubbs, R. (2002), 'ASEAN Plus Three: emerging East Asian regionalism?' Asian Survey, vol. 42, no. 3, pp. 440-455. https://doi.org/10.1525/as.2002.42.3.440

The World Bank (2005), Global Economic Prospects: Trade, Regionalism, and Development, Washington, DC: The World Bank.

Wendt, A. (1994), 'Collective identity formation and the international state,'American Political Science Review, vol. 88, no. 2, pp. 384-396. https://doi.org/10.2307/2944711

Yeo, L. H. (2003), Asia and Europe: The Development and Different Dimensions of ASEM, London: Routledge. https://doi.org/10.4324/9780203609996

Yeung, M. T.; Perdikis, N. \& Kerr, W. A. (1999), Regional Trading Blocs in the Global Economy: The EU and ASEAN, Cheltenham: Edward Elgar. 